\title{
THE EFFECT OF MULTIMEDIA USE ON UNDERSTANDING CONCEPT OF PG-PAUD STUDENTS IN COURSE COGNITIVE DEVELOPMENT AND CREATIVITY OF EARLY CHILDHOOD IN UNSRI PALEMBANG Oleh:
}

\author{
Hasmalena ${ }^{1}$, Rukiyah, Mahyumi Rantina
}

Universitas Sriwijaya

\begin{abstract}
The Effect of multimedia usage on PG-PAUD student concept understanding in cognitive development and creativity course of early childhood has been done on PGPAUD Student semester three in Palembang Sriwijaya University. The type of research used is experiment with One Shoot Case Study descriptions, with sampling technique that is purposive sampling. The sample in the pre-experiment class is 27 and the post-test class is 28. The data collection technique is written essay, interview and documentation. Result of data analysis obtained is 80,71, while result of hypothesis test based on t-test obtained $t \_c o u n t>t \_t a b l e ~ o r ~ g o t ~ t \_c o u n t=6,76>t \_t a b l e=4,83$, hence $H o$ refused and $\mathrm{Ha}$ accepted, thus there effect multimedia usage to understanding the concept of PG-PAUD students in courses of cognitive development and creativity of early childhood. With assessment indicators Redefining a concept, Classifying objects according to certain traits according to their concepts, Providing examples of concepts, Using, utilizing and selecting specific procedures. So the use of multimedia to understanding the concept of the students is very influential to improve understanding of the concept..
\end{abstract}

Keyword: Multimedia Usage, Conceptual Understanding, Early Childhood Education

\begin{abstract}
Abstrak: Pengaruh penggunaan multimedia pada pemahaman konsep siswa PG-PAUD dalam perkembangan kognitif dan kreativitas anak usia dini telah dilakukan pada mahasiswa PG-PAUD semester tiga di Universitas Sriwijaya Palembang. Jenis penelitian yang digunakan adalah eksperimen dengan deskripsi One Shoot Case Study, dengan teknik pengambilan sampel yaitu purposive sampling. Sampel dalam kelas pra-eksperimen adalah 27 dan kelas post-test adalah 28 . Teknik pengumpulan data adalah esai tertulis, wawancara dan dokumentasi. Hasil analisis data yang diperoleh adalah 80,71, sedangkan hasil uji hipotesis berdasarkan t-test diperoleh t_count $>\mathrm{t}$ _table atau mendapat $t \_c o u n t=6,76>$ t_table $=4,83$, maka Ho ditolak dan Ha diterima, sehingga ada pengaruh penggunaan multimedia. untuk memahami konsep siswa PG-PAUD dalam kursus pengembangan kognitif dan kreativitas anak usia dini. Dengan indikator penilaian Mendefinisikan kembali konsep, mengklasifikasikan objek sesuai dengan sifat-sifat tertentu sesuai dengan konsep mereka, Memberikan contoh konsep, Menggunakan, memanfaatkan dan memilih prosedur tertentu. Jadi penggunaan multimedia untuk memahami konsep siswa sangat berpengaruh untuk meningkatkan pemahaman konsep tersebut
\end{abstract}

Kata Kunci: Pemanfaatan multimedia, Pemahaman konsep, PAUD.

\section{INTRODUCTION}

The course of Cognitive Development and Early Childhood Creativity (3 SKS), is one of compulsory subjects in Early Childhood Education Program (PG-PAUD), in this course aims to direct students to be able to plan stimulation, apply, to develop cognitive and early childhood creativity. In detail, this study examines the nature of cognitive, early childhood cognitive characteristics, cognitive classification,

'Universitas Sriwijaya, Email: lena.bunda@yahoo.ac.id 
knowledge building in children, multiple intelligences, cognitive developmental theory, cognitive development methods, media and cognitive development models according to applicable curriculum, creative theory, cognitive relations and creativity, cognitive stimulation and creativity of early childhood through math and game science games in early childhood. Therefore the course of Cognitive Development and Creativity is an important aspect in early childhood development.

The reality of the lectures that took place during this time, using only lecture methods and presentations on teaching materials with many terms of early childhood and psychology. This phenomenon resulted in students not understanding concretely about the development of cognitive and creativity of AUD. How can they as future PAUD teachers teach, stimulate, and develop AUD cognitive and creativity, if an early childhood student does not understand this. In addition, the atmosphere of lectures that occur in one direction becomes boring. Students are less passionate, passive in participating, lack of curiosity and many difficulties in sharing and helping of knowledge activities. Both activities are very useful to help students understanding in lecturing, so it is not easy for lecturers to teach with scientific approach in applying curriculum based KKNI, as well as university students, it is difficult to get a thorough understanding of related subject matter since there are not many examples of real and reference sources either in the form of pictures or videos on the implementation of early childhood mathematics and science learning to develop the cognitive and creativity of AUD that will be made student referral in learning practice.

Multimedia is the use of computers to present and combine text, sound, images, animation, audio, and video with tools and links so users can navigate, interact, work and communicate. Meanwhile, According to Arsyad (2013, p. 141), "multimedia is a medium of audiovisual tools that audible means can be heard and and tools that visible means can be viewed. Tools are audiovisual point to make way to communicate to be effective. Audiovisual media is an affordable form of teaching media then Kustiono argues that learning media such as audiovisual is a form of media both software and hardware that is able to convey the message of learning in an auditive as well as visual means the messages conveyed through the channels of the senses of listener and sight as well Audiovisual media is a media that has elements of sound and image elements (Daryanto 2013, p. 46). In addition, According to Priyono (2015), that media is an intermediary or messenger of the message sender to the recipient of the message, related to media learning is anything that can be used to convey messages from the sender of the message to the recipient of the message so as to stimulate thoughts, feelings and attention learners to achieve learning objectives. Based on the above description is meant by the use of multimedia in this study is the use of media that involves some functions both through hearing and visual media also can affect the mind and attention of students to achieve goals such as: making ppt and making animated video in learning.

The function of learning media according to Sutikno (2013) is as follows:

1. Attract students' attention

2. Helps to accelerate understanding in the learning process

3. Clarify the presentation of the message so as not to be verbalistic

4. Overcoming the limitations of space

5. Learning is more communicative and productive

6. Learning time can be conditioned

7. Eliminate the boredom of students in learning 
8. $\quad$ Serving diverse student learning styles and

9. increase the level of liveliness or involvement of students in learning activities.

Understanding is a person's ability to understand or understand something. In other words, understanding is knowing something and can see it in many ways. Someone is said to understand a thing when he can give an explanation and imitate it by using his own words. Winkel $(2004, \quad$ p. 274) suggests that comprehension includes the ability to grasp the meaning and meaning of the material being studied.

Bloom in Jonah (2009) explains that understanding is an ability to absorb the meaning of matter or material being studied. Understanding is a cognitive level $\mathrm{C}$ in language called Comprehension. In addition, Arifin (2003) explains understanding is an ability that students are able to change, interpret and explore. From some of the above explanation can be concluded that the understanding is the result of teaching and learning process characterized by the ability to explain or define an information with his own words. Understanding is the ability to explain and interpret something. Understanding is not just knowing, which is usually only limited to recall experience and produce what ever learned. Understanding is more than just knowing, because understanding involves a dynamic mental process. Understanding is a gradual process that has its own capabilities such as translating, interpreting, exploration, application, analysis, synthesis, and evaluation.

The concept according to Umar (2004: 51) concept is a number of theories related to an object. Concepts are created by grouping and grouping certain objects that share the same traits. Meanwhile, according to Soedjadi cited by Saifuddin (2014: 67) the concept is an abstract idea that can be used to make a classification or classification that is generally expressed by a term or series of words. Based on the above understanding can be concluded that the concept is an abstract idea with a number of theory related objects and classification expressed by a series of words

\section{RESEARCH METHODS}

The research method used in this research is Pre-experimental design method with One-Shot-Case-Study design (Sugiyono, 2015: 110). Darmadi's experimental research (2014: 217) is the only research method that can test the hypothesis of causal relationships. In line with the above opinion of experts according to Sugiono (2015: 107) experimental research can be interpreted as a research method used to seek the influence of certain treatment against others in controlled conditions. So based on the opinion of the experts above can be said that experimental research is a research method that tested the causal hypothesis used to look for the influence of certain treatment.

\section{Research variable}

The research variables according to Sugiyono (2015: 60) is anything in the form of what is determined by the researchers to be studied so that obtained information about it, then drawn conclusions. According Arikunto (2012: 161) variable research is the object of research or what the point of attention of a study. Meanwhile, according to Selegi (2013: 49) variable is the characteristic to be observed from an observation. Based on the above description it can be said that the research variable is the object of research in the form of what is determined by the researcher who became the point of attention of a study to be observed and studied then drawn conclusions. As for the variables in this study are:

1. Independent variable (x): Multimedia Implementation

2. Dependent variable (y): Student Ability PG PAUD 


\section{Time and Place of Study}

Place of this research in Prodi PGPAUD Department of Education Faculty of Teacher Training and Education Science Campus PGSD Km 5,5 Palembang. The time of the research is conducted on students of 3rd semester of 2017.

\section{Population Research}

Which will be the population in this study is all students PG PAUD 3rd semester Palembang 2017, which consists of 28 students.

Table 2.1 Research Population

\begin{tabular}{|l|c|}
\hline \multicolumn{1}{|c|}{ Class } & $\begin{array}{c}\text { Number of } \\
\text { Students }\end{array}$ \\
\hline $\begin{array}{l}\text { Students PG- PAUD } \\
\text { semester 3 Palembang in } \\
2017\end{array}$ & \\
\hline
\end{tabular}

\section{Sample}

In this research, the sample that will be used is the 3rd semester student of 2017 which amounted to 30 students, consisting of 28 women and 2 men, related to the Cognitive Development and Creativity AUD course, sampling technique using "Purposive Sampling".

\section{Research procedure} three stages:

The research procedure consists of

\section{Preparation Phase}

1. Conduct research by interviewing students in the 3rd semester of 2017

2. Create syllabus and lecture tools

3. Setting up Camera and Handycame for making learning video using multimedia

4. Developing research instruments (grid questions) along with key answers and scoring guidelines

5. Prepare props such as Infocus

6. Validate learning tools and research instruments

7. Testing Instruments and Tests

\section{Implementation phase}

Determining the sample of research by conducting experiments with the design of one shot case study, namely the first treatment (treatment) is the experimental group (sample class).

\section{Final stage (data management)}

a) Mensor a post-test result

b) Convert the score to a value

Table 2.2 Concept Understanding Instruments

\begin{tabular}{|c|c|c|c|c|c|}
\hline \multirow[t]{2}{*}{ No. } & \multirow[t]{2}{*}{ Aspect of observed } & \multicolumn{4}{|c|}{ Score } \\
\hline & & 1 & 2 & 3 & 4 \\
\hline 1. & $\begin{array}{l}\text { 1. Redefine a } \\
\text { concept }\end{array}$ & & & & \\
\hline 2. & $\begin{array}{l}\text { Classify objects } \\
\text { according to certain } \\
\text { traits according to } \\
\text { their concepts }\end{array}$ & & & & \\
\hline 3. & $\begin{array}{l}\text { Give examples of } \\
\text { concepts }\end{array}$ & & & & \\
\hline 4. & $\begin{array}{l}\text { Use, utilize and } \\
\text { select certain } \\
\text { procedures } \\
\text { Apply the concept }\end{array}$ & & & & \\
\hline 5. & Apply the concept & & & & \\
\hline
\end{tabular}

\section{Data analysis technique}

Technique Analysis of data to be used in this research is statistical test paramtrik t (t-test). Statistical tests are used to test the rejection or acceptance of the null hypothesis, provided that the sample is homogeneous and normally distributed. The value of the test results obtained in the experimental class and control class is arranged in the frequency distribution table. In this study using data normality test and hypothesis test. After getting the next value determine the criteria in accordance with the value obtained.

Table 2.3 Conversion Score

\begin{tabular}{|c|c|c|}
\hline Number & & description \\
\hline $85-100$ & A & Very good \\
\hline $71-84$ & B & good \\
\hline $60-70$ & C & enough \\
\hline $50-59$ & D & less \\
\hline
\end{tabular}




\begin{tabular}{|l|l|l|}
\hline$<49$ & $\mathrm{E}$ & Less once \\
\hline
\end{tabular}

\section{Hypothetic Test}

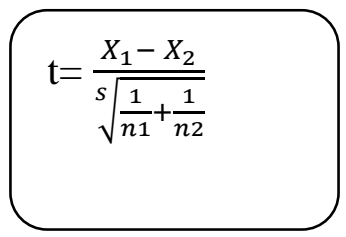

(Sudjana, 2009:239)

\section{RESULT AND DISCUSSION}

In this study the researchers used the average test before the treatment seen from the assignment value of 3 semester students PG. PAUD 2017 Palembang. Obtain the average value and standard deviation value for each indicator that can be seen in the table.

Table 3.1 Data Student Average Score On Each Indicator

\begin{tabular}{|c|c|c|c|}
\hline class & $\begin{array}{c}\text { High } \\
\text { score }\end{array}$ & $\begin{array}{c}\text { Low } \\
\text { score }\end{array}$ & Average \\
\hline Pre test & 80 & 45 & 63 \\
\hline
\end{tabular}

Data from this study is the average posttest. This posttest is done to see the effect of multimedia usage on PG student concept understanding. PAUD 3rd semester on cognitive development and kretivitas early childhood in Palembang.

Table 3.2 Distribution of Frequency of Concept Understanding

\begin{tabular}{|c|c|c|c|}
\hline category & $\begin{array}{c}\text { Value } \\
\text { range }\end{array}$ & Frequency & Percentage \\
\hline A & $\begin{array}{c}85- \\
100\end{array}$ & 11 & $39 \%$ \\
\hline B & $\begin{array}{c}71- \\
84\end{array}$ & 12 & $43 \%$ \\
\hline C & $\begin{array}{c}60- \\
70\end{array}$ & 5 & $18 \%$ \\
\hline D & $\begin{array}{c}50- \\
59\end{array}$ & - & - \\
\hline E & $<49$ & - & - \\
\hline
\end{tabular}

In this study many samples consist of 28 students in the 3rd semester of Palembang. The researcher analyzed the students 'pre-test value on the students' concept of understanding by finding the mean value. There is an average score before treatment. Here are the significant differences in pre test and post test results seen in the following table:

Table 3.3 Pre Test Results And Posttest

\begin{tabular}{|c|c|c|c|c|}
\hline No & class & $\begin{array}{c}\text { High } \\
\text { score }\end{array}$ & $\begin{array}{c}\text { Low } \\
\text { score }\end{array}$ & average \\
\hline 1. & $\begin{array}{c}\text { Pre } \\
\text { test }\end{array}$ & 80 & 45 & 63 \\
\hline 2. & $\begin{array}{c}\text { Post } \\
\text { test }\end{array}$ & 95 & 60 & 80 \\
\hline
\end{tabular}

Test of Normality of Pre-Test Data

Pre-test results obtained by students who have been determined by lecturers cognitive development and creativity courses can be seen paada following table

Table 3.4 Criteria Student Learning Results

\begin{tabular}{|c|c|c|}
\hline Number & & description \\
\hline $85-100$ & A & Very good \\
\hline $71-84$ & B & good \\
\hline $60-70$ & C & enough \\
\hline $50-59$ & D & less \\
\hline$<49$ & E & Less once \\
\hline
\end{tabular}

Students who scored 85 - 95 with the criteria "Very Good" is not obtained by students, then students who get the score 71 - 84 with the criteria "Good" as much as 2 students, then students who get the value of 60 - 70 with criteria "Enough" 19 students, while with the criteria "less" with a range of values 50 - 59 as many as 5 students, 1 student get the criteria "Less Once". from the number of students as many as 30 people got the highest score of 83 and the lowest value 0 with an average of 74. From the data of the experimental class test results, it is necessary to create a range (interval) to facilitate the data entry to standard deviation.

Highest score: 80

Lowest score: 45

a) Range $=$ largest value - lowest value $=$ $80-45=35$

b) Many interval classes

$$
=1+3.3 \log n
$$


$=1+3.3 \log 27$

$=1+3.3(1.43)$

$=5.71$ rounded to 6

So, long of class interval taken 6 (six) classes.

Class interval length $=($ class range $)$ / (multiple classes)

$=35 / 6=5.83$ rounded to 6

Thus, the length of the interval class taken is 6

c) Frequency distribution table

Table 3.5 Frequency Distribution of Pre Test Value

\begin{tabular}{|c|c|c|c|c|c|}
\hline $\begin{array}{c}\text { Interv } \\
\text { al }\end{array}$ & $\boldsymbol{f}_{\boldsymbol{i}}$ & $\boldsymbol{X}_{\boldsymbol{i}}$ & $\boldsymbol{f}_{\boldsymbol{i}} \cdot \boldsymbol{X}_{\boldsymbol{i}}$ & $\boldsymbol{X}_{\boldsymbol{i}}{ }^{2}$ & $\boldsymbol{f}_{\boldsymbol{i}} \cdot \boldsymbol{X}_{\boldsymbol{i}}{ }^{\mathbf{2}}$ \\
\hline $45-$ & 2 & 47, & 95 & 2256, & 4512,5 \\
50 & & 5 & & 25 & \\
\hline $51-$ & 4 & 53, & 214 & 2862, & 11449 \\
56 & & 5 & & 25 & \\
\hline $57-$ & 7 & 59, & 416,5 & 3540, & 24781,7 \\
62 & & 5 & & 25 & 5 \\
\hline $63-$ & 5 & 65, & 327,5 & 4290, & 21451,2 \\
68 & & 5 & & 25 & 5 \\
\hline $69-$ & 6 & 71, & 429 & 5112, & 30673,5 \\
74 & & 5 & & 25 & \\
\hline $75-$ & 3 & 77, & 232,5 & 6006, & 169937, \\
80 & & 5 & & 25 & 1 \\
\hline sum & $\mathbf{2}$ & $\mathbf{3 7}$ & $\mathbf{1 7 1 4}$, & $\mathbf{2 4 0 6 7}$ & $\mathbf{1 1 0 8 8 6}$, \\
& $\mathbf{7}$ & $\mathbf{5}$ & $\mathbf{5}$ & $\mathbf{5}$ & $\mathbf{7 5}$ \\
\hline
\end{tabular}

From the frequency distribution table above, it can be seen that the frequency of each class of interval with frequency ( $\left.f \_i\right)$ is the most in the class of $57-62$ as many as 7 students, while for the lowest grade 45 - 50 are 2 students.

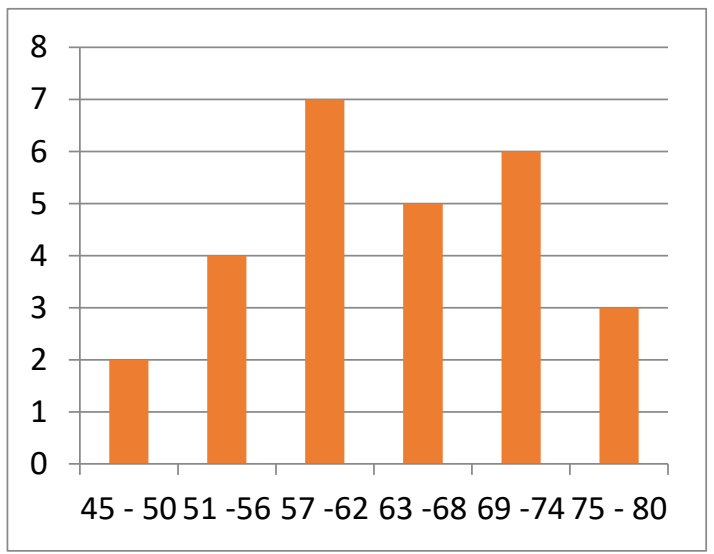

Graph of frequency distribution of pre test value

d) Average grade of experiment

$$
\begin{aligned}
\bar{X} & =\frac{\sum f i . X i}{\sum f i} \\
& =\frac{1714,5}{27} \\
& =63,5
\end{aligned}
$$

e) Mode

$$
\begin{aligned}
\text { Mo } & =b+p\left[\frac{b 1}{b i+b 2}\right] \\
& =56,5+6\left[\frac{3}{3+2}\right] \\
& =56,5+3,6 \\
& =60,1
\end{aligned}
$$

f) Standard deviation

$$
\begin{gathered}
S^{2}=\frac{n \sum f i x i^{2}-\left(\sum f i x i\right)^{2}}{n(n-1)} \\
=\frac{27(110886,75)-(1714,5)^{2}}{27(27-1)} \\
=\frac{2993942,25-2939510,25}{27(26)} \\
=\frac{5432}{702} \\
S^{2}=77,53 \\
S=\sqrt{77,53} \\
S=8,80
\end{gathered}
$$

From the mean, mode, and standard deviation can be sought curve coefficient curve by using Karl Pearson formula, namely:

$$
\begin{aligned}
\mathrm{Km}=\left[\frac{\bar{X}-M o}{S}\right] \\
=\left[\frac{63,5-60,1}{8,80}\right] \\
=\left[\frac{3,4}{8,80}\right] \\
=0,38
\end{aligned}
$$

Based on the above data calculation, the $\mathrm{Km}$ value is 0.38 because the $\mathrm{Km}$ value is 0.38 and the price is between $(-1)$ and (1), then the pre-test class can be distributed normally.

\section{Test Normality of Post-Test Data}

Pre-test results obtained by students who have been determined by lecturers cognitive development and creativity. students who get the score 85 - 95 with the criteria "Very Good" as many as 11 students, then students who get the score 
71 - 84 with the criteria "Good" as many as 12 students, then students who get the value of 60 - 70 with criteria "Enough" students. From the number of students as many as 28 people got the highest score of 95 and the lowest score of 60 with an average of 80 . From the data of the experimental class test results, it is necessary to create a range (interval) to facilitate the data entry to standard deviation.

Range

$=$ largest value - lowest value

$=95-60=35$

Many interval classes

$=1+3.3 \log \mathrm{n}$

$=1+3.3 \log 28$

$=1+3.3(1.44)$

$=5.75$ rounded to 6

So, long of class interval taken 6 (six) classes.

Length of interval class

$=($ class range $) /$ (multiple classes $)$

$=35 / 6=5.83$ rounded to 6

Thus, the length of the interval class taken is 6

Frequency distribution table

Table 3.6 Frequency Distribution of Pre Test Value

\begin{tabular}{|c|c|c|c|c|c|}
\hline $\begin{array}{c}\text { Interv } \\
\text { al }\end{array}$ & $\boldsymbol{f}_{\boldsymbol{i}}$ & $\boldsymbol{X}_{\boldsymbol{i}}$ & $\begin{array}{c}\boldsymbol{f}_{\boldsymbol{i}} \cdot \\
\boldsymbol{X}_{\boldsymbol{i}}\end{array}$ & $\boldsymbol{X}_{\boldsymbol{i}}^{\mathbf{2}}$ & $\boldsymbol{f}_{\boldsymbol{i}} \cdot \boldsymbol{X}_{\boldsymbol{i}}^{\mathbf{2}}$ \\
\hline $60-65$ & 3 & 62, & 187, & 3906,2 & 11718,7 \\
& & 5 & 5 & 5 & 5 \\
\hline $66-71$ & 2 & 68, & 137 & 4692,2 & 9384,5 \\
& & 5 & & 5 & \\
\hline $71-77$ & 4 & 74, & 298 & 5550,2 & 22201 \\
& & 5 & & 5 & \\
\hline $78-83$ & 8 & 80, & 644 & 6480,2 & 51842 \\
& & 5 & & 5 & \\
\hline $84-89$ & 4 & 86, & 346 & 7482,2 & 29929 \\
& & 5 & & 5 & \\
\hline $90-95$ & 7 & 92, & 647, & 8556,2 & 59893,7 \\
& & 5 & 5 & 5 & 5 \\
\hline sum & $\mathbf{2}$ & $\mathbf{4 6 5}$ & $\mathbf{2 2 6}$ & $\mathbf{3 6 6 6 7}$, & $\mathbf{1 8 4 9 6 9}$ \\
& $\mathbf{8}$ & & $\mathbf{0}$ & $\mathbf{5}$ & \\
\hline
\end{tabular}

From the above frequency distribution table it can be seen that the frequency of each class of interval having frequency ( $\mathrm{f} \_\mathrm{i}$ ) is the most in the class of $78-83$ as many as 8 students, while for the lowest grade 66 - 71 are 2 students.

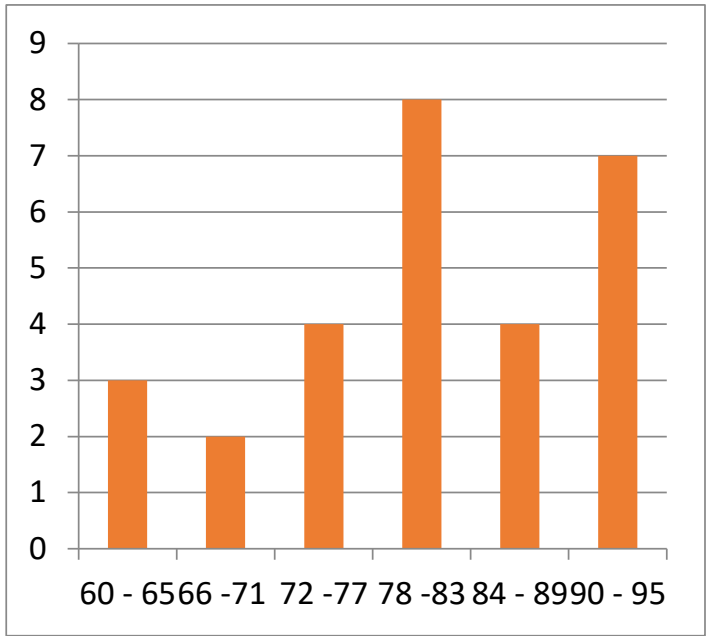

Graphical image of frequency distribution of post-test value

d. Average grade of experiment

$$
\begin{aligned}
\bar{X} & =\frac{\sum f i . X i}{\sum f i} \\
& =\frac{2260}{28} \\
& =80,71
\end{aligned}
$$

e. Mode

$$
\begin{aligned}
\text { Mo } & =\mathrm{b}+\mathrm{p}\left[\frac{b 1}{b i+b 2}\right] \\
& =77,5+6\left[\frac{4}{4+4}\right] \\
& =77,5+6\left[\frac{4}{8}\right] \\
& =77,5+3 \\
& =80,5
\end{aligned}
$$

f. Standard deviation

$$
\begin{aligned}
S^{2} & =\frac{n \sum f i x i^{2}-\left(\sum f i x i\right)^{2}}{n(n-1)} \\
& =\frac{28(184969)-(2260)^{2}}{28(28-1)} \\
& =\frac{5179132-5107600}{28(27)} \\
& =\frac{71532}{756} \\
S^{2} & =94,61 \\
S & =\sqrt{94,61}
\end{aligned}
$$




$$
S=9,72
$$

From the mean, mode, and standard deviation can be sought curve coefficient curve by using Karl Pearson formula, namely:

$$
\begin{aligned}
\mathrm{Km} & =\left[\frac{\bar{X}-M o}{S}\right] \\
& =\left[\frac{80,71-80,5}{9,72}\right] \\
& =\left[\frac{0,21}{9,72}\right] \\
& =0,021
\end{aligned}
$$

Based on the above data calculation, the $\mathrm{Km}$ value is 0.021 because the $\mathrm{Km}$ value is 0.021 and the price is between (1) and (1), then the pre-test class can be distributed normally.

\section{Formulation of hypotheses}

The steps that researchers do in taking the conclusion of the hypothesis are as follows: Based on the formulation of the hypothesis, namely:

H_0: there is no effect of multimedia usage on understanding PG-PAUD student concepts. Early childhood education in the cognitive development and creativity of early childhood at UNSRI Palembang.

H_a: there is influence of multimedia usage to understanding PGPAUD student concept. Early childhood education in the cognitive development and creativity of early childhood at UNSRI Palembang.

\section{Specifies t_count}

After calculating the average value and standard deviation

students then do t-test calculations. To get the value $X \_1$ using the pre-test value after it obtained the result of the average value and standard deviation.

$$
S^{2}=\frac{(n i-1) S_{2}^{1}+(n 1-1) S_{2}^{2}}{n i+n 2-2}
$$

Then compare the mean value and standard deviation posttest.

T-test calculation

Tabel 3.7

Nilai Rata-Rata Dan Simpangan Baku

\begin{tabular}{|c|c|}
\hline Kelas Post -test & Kelas Pre-test \\
\hline $\bar{X}_{1}=80,71$ & $\bar{X}{ }^{2}=63,5$ \\
$S_{1}{ }^{2}=94,61$ & $S_{2}{ }^{2}=94,61$ \\
$n_{1}=28$ & $n_{2}=27$ \\
& \\
\hline
\end{tabular}

With the values contained in the table, then performed the following calculations:

$$
\begin{aligned}
S^{2} & =\frac{(n i-1) S_{2}^{1}+(n 1-1) S_{2}^{2}}{n i+n 2-2} \\
& =\frac{(28-1) 94,61+(27-1) 86,23}{53} \\
& =\frac{2554,47+224,98}{53} \\
& =\frac{4796,45}{53} \\
S^{2} & =90,49 \\
S & =\sqrt{90,49} \\
S & =9,51
\end{aligned}
$$

Then t_count is searched by the formula:

$$
\begin{aligned}
\mathrm{t} & =\frac{x 1-x 2}{\sqrt[s]{\frac{1}{n 1}+\frac{1}{n 2}}} \\
& =\frac{80,71-63,5}{9,51} \sqrt{\frac{1}{28}+\frac{1}{27}} \\
& =\frac{16,71}{\sqrt[9,51]{\frac{1}{28}+\frac{1}{27}}} \\
& =\frac{16,71}{\sqrt[9,51]{0,072}} \\
& =\frac{16,71}{9,51 \times 0,26} \\
& =\frac{16,71}{2,47} \\
t_{\text {hitung }} & =6,76
\end{aligned}
$$


Specify t_tabel

Finding t_table for $\mathrm{t}(1-\mathrm{a})$ is:

$$
\begin{aligned}
\mathrm{dk} & =n_{1}+n_{2}-2 \\
& =28+27-2 \\
\mathrm{dk} & =53
\end{aligned}
$$

to know t_table, because it is not contained in the distribution table with $\mathrm{dk}$ $=\mathrm{n}-2=53$ with $95 \%$ confidence level calculated by the interpolation formula as follows:

$\frac{60-(d k)}{(d k)-40}=\frac{t(0,95)(60)-x}{x-(0,95)(40)}$

$\frac{60-53}{53-40}=\frac{1,671-x}{x-1,684}$

$\frac{7}{13}=\frac{1,671-x}{x-1,684}$

$0,53 \mathrm{x}-0,89=1,671-\mathrm{x}$

$0,53 \mathrm{x}+\mathrm{x}=1,671+0,98$

$0,53 \mathrm{x}=2,561$

$X=\frac{2,561}{0,53}=4,83$

Based on the above data calculation, t_ (table) (0.95) obtained at 4.83 while t_count 6.76 with a significance level of 0.05 greater than t_tabel 4.83 so, from the calculation results obtained 6.76> 4,83 and the accepted hypothesis is reject Ho accepted Ha or t_count $>t$ t_tabel. Finally it can be concluded that there is influence of the use of multimedia to understanding the concept of PG-PAUD students in the course of cognitive development and creativity of early childhood at UNSRI Palembang.

\section{Discussion}

Researchers used two types of tests: pre-test and post test. The number of students consists of 28 on the pre-test and 27 on the post-test so if totaled the sample is 55 students of PG 3 semester. PAUD UNSRI Palembang. The process of this research was conducted seven times. In the pre-test class students are not given treatment (treatment) while for the posttest class is given treatment (treatment) in the form of the use of multimedia understanding of the concept of students in the cognitive and creativity of early childhood as much as the purpose of meeting. Learning on both tests with 3 credits. Furthermore, students are given the opportunity to discuss (presentation) in the class with the same topic with the post-test class that has been given the previous treatment. The test results that have been obtained from each class are assessed based on the rubric and indicator that have been determined. These values are then analyzed or processed to obtain a description of the differences in the increased understanding of inter-class concepts given treatment and those not treated.

In the post-test that has been given treatment in the form of multimedia usage there is a significant influence that can be seen from the difference of student test result between pre-test value and post-test value. In the pre-test class of 27 students with the total test results of 1715 , the highest score is 80 and the lowest score 45 , with an average of 63 . As for the posttest value given treatment (treatment) in the form of the use of multimedia. The overall test results amounted to 2250 with an average grade value of 80 , the highest value obtained is 95 with the lowest value of 60. Based on the results of these calculations then there is a significant quantitative influence between the two values.

While the qualitative influence between pre-test and post-test that can be seen teaching and learning process. The use of multimedia (treatment) in the cognitive development and creativity class in the post-test class shows that their learning motivation is high and enthusiastic in the learning process increase, it is caused by the treatment given in this case is the use of multimedia at every meeting, the student also in get used to play an active role in the learning process in the classroom. Given the many benefits that the use of multimedia itself. Students are more active and enthusiastic 
in following the lectures. While in terms of understanding the concept of students also showed improvement, more students understand a topic of learning with proven from the results obtained values. Furthermore, in the pre-test class that is not given the previous treatment to get the opposite result is the motivation and the spirit of learning is not visible. In fact, it tends to be monotonous. This is because the pre-test class does not get treatment.

After obtaining the results of student tests the researcher conducted an analysis of the test results. The analysis that has been done is using the t-test consisting of normality test and hypothesis test. Based on the results obtained in the pre-test class, the normality test obtained for $\mathrm{Km}=0.38$ and the price lies between (-1) and (1) so that it can be said that the control class data can be normally distributed. Furthermore, in the post-test class is obtained $\mathrm{Km}=0.21$ and the price lies between (-1) and (1) so that it can be said that the post-test class is normally distributed.

Furthermore after it is known that all data is normally distributed then the next stage is testing the hypothesis by showing that the final test result for the post-test class obtained t_count $=6.76$ and $t_{\text {_ }}$ (table) with the level of trust 0.05 and $\mathrm{dk}=53$ obtained $\mathrm{t}_{-}$(table) $=4.83$ thus t_count>t_(table) so it can be said that there is influence of the use of multimedia to understanding the concept of PGPAUD students in the course of cognitive development and creativity of early childhood at UNSRI Palembang.

\section{CONCLUSIONS}

Based on the results of analysis and discussion that have been obtained by researchers from research that has been done, it can be obtained conclusion as follows:

Provision of treatment in the form of the use of multimedia is a medium that can encourage interest in studying students to be more active in learning and enthusiastic in following the learning. The use of multimedia in every meeting affect the understanding of student concepts in the cognitive development and creativity of early childhood. This can be proved by the average result of the students test in the pre-test class is 63 in the post-test class of 63 .

After getting the test result data then the researcher doing data processing, then got the result of calculation with t_table $=4,83$ whereas t_count $=6,67$ with significant level $0,05, \mathrm{t}$ _count $=6,76$ bigger than t_tabel $=4,83$, so from the calculation results obtained t_count = 6.76> $\mathrm{t}_{\text {_ }}($ table $)=4.83$ then it can be concluded there is influence of multimedia usage to understanding concept. Thus the alternative hypothesis (Ha) is accepted and the null hypothesis (Ho) is rejected.

\section{Suggestions}

In accordance with the results of research and conclusions derived from this study, then the following are some suggestions to be given by researchers:

For students, the use of multimedia given at the time of learning can be used as a basis to improve the understanding of the concept by knowing his own ability and stimulate him to make improvements so as to improve the learning outcomes.

For lecturers, the use of multimedia provided in each lecture can be used to determine the ability of students in mastering the material that has been taught so that lecturers can take more steps to improve or repeat the material back if the material taught has not been mastered properly so as to improve student learning outcomes with optimal.

For study programm, as an information and input materials in determining the steps of better learning as an effort to improve the quality of learning

\section{REFERENCES}


Arikunto,Suharsimi,dkk.

(2012).

Prosedur Penelitian Suatu Pendekatan Praktek,Jakarta : Rineka Cipta

Arsyad, Azhar. (2013). Media Pembelajaran. Jakarta: PT Raja Grafindo Persada

Daryanto, (2013). Media Pembelajaran Peranannya sangat penting dalam mencapai Tujuan Pembelajaran, Jogyakarta:Gava media

Priyono, E. (2015). Meningkatkan Kabiasaan Mencuci Tangan Pada Siswa Sekolah Dasar Melalui Penerapan Alat Bantu Media Audio Visual Dalam Kegiatan Pembelajaran Pendidikan Kesehatan (Doctoral dissertation, Universitas Pendidikan Indonesia).

Rukiyah, (2015). Pengembangan Model Pembelajaran Berbasis E-Learning dalam mata kuliah Pengembangan Kognitif dan Kreatifitas Anak Usia Dini.Laporan Penelitian Universitas Sriwijaya.

Sudjana. (2009). Metoda Statistika. Bandung:Tarsito.

Sugiyono. (2012). Statistik Untuk Penelitian. Bandung: Alfabeta.

Sugiyono. (2015). Metode Penelitian Pendidikan Pendektan Kuantitatif, Kualitatif, Kualitas, dan $R \& D$. Bandung:Alfabeta.

Sutikno, Sobry (2013) Belajar dan Pembelajaran, Bandung:Prosfect

Umar, Husain. (2004). Metode Riset Ilmu Administrasi. Jakarta:Gramedia Pustaka Utama. 